\title{
Penerapan Pembelajaran Kooperatif Tipe STAD Untuk Memotivasi Membaca Indah Teks Puisi Siswa Kelas VII SMPK Sinar Pelita Mukusaki Kecamatan Wewaria Kabupaten Ende Tahun Ajaran 2020/2021
}

\author{
Falentius Bata \\ Program Studi pendidikan Bahasa dan Sastra Indonesia, Universitas Flores \\ Email falentinusbata@gmail.com
}

\begin{abstract}
Abstrak. Permasalahan yang diangkat dalam penelitian ini adalah bagaimanakah penerapan Pembelajaran Kooperatif Tipe STAD untuk memotivasi membaca indah teks puisi siswa kelas VII SMPK Sinar Pelita Mukusaki Kecamatan Wewaria, Kabupaten Ende, Tahun Ajaran 2020/2021. Penelitian ini bertujuan untuk mengetahui dan mendeskripsikan penerapan pembelajaran Kooperatif Tipe STAD untuk memotivasi membaca indah teks puisi siswa Kelas VII SMPK Sinar Pelita Mukusaki Kecamatan Wewaria, Kabupaten Ende, Tahun Ajaran 2020/2021. Pendekatan yang digunakan dalam penelitian ini adalah pendekatan kuantitatif merupakan penelitian yang mengumpulkan data dan memberikan penafsiran terhadap hasilnya dengan menggunakan angka-angka. Yang mana pendekatan ini lebih brpijak pada logika deduktif dengan mengedepankan angka-angka teruji, terukur, dan teramati. Data yang digunakan adalah data lisan, yaitu data yang diambil dari penampilan pada saat membaca puisi siswa kelas SMPK Sinar Pelita Mukusaki Kecamatan Wewaria, Tahun Ajaran 2020/2021. Teori yang digunakan dalam penelitian ini adalah teori strategi belajar mengajar, teori evaluasi pembelajaran, teori ketrampilan membaca. Hasil penelitian menunjukkan bahwa kemampuan membaca indah teks puisi dengan penerapan Pembelajaran Kooperatif Tipe STAD Pada Siswa KelasVII SMPK Sinar Pelita Mukusaki Kecamatan Wewaria, Kabupaten Ende Tahun Ajaran 2020/2021 mencapai kecakapan dengan nilai rata-rata $75 \%$. Hal ini dapat dibuktikan dengan nilai ketuntasan siswa 80-85 dengan jumlah siswa sebanyak 15 orang, dengan kriteria baik dengan presentase $75 \%$ dan dengan standar terendah $\leq 70$ dengan jumlah siswa sebanyak 5 orang, dengan presentase $25 \%$.
\end{abstract}

Kata kunci: Membaca Indah Teks Puisi 


\section{PENDAHULUAN}

Lembaga pendidikan sekarang ini, sudah mengetahui bahwa pembelajaran bahasa merupakan kunci sukses bagi segala kegiatan pendidikan. Pembelajaran bahasa adalah belajar berkomunikasi. Oleh karena itu, pembelajaran bahasa Indonesia diarahkan untuk meningkatkan kemampuan peserta didik untuk berkomunikasi dalam Bahasa Indonesia dengan baik dan benar, baik secara lisan maupun tulisan. Dalam berkomunikasi dengan bahasa ada empat komponen yang tercakup di dalamnya yaitu menurut Semi (2007: 2). (1) Keterampilan menyimak, Keterampilan berbicara, (3) keterampilan membaca, (4) Keterampilan menulis.Keempat komponen itu didalam pelaksanaanya saling terkait hingga harus dilaksanakan sejalan dan terpadu. Keterampilan berbahasa merupakan bentuk komunikasi atau menyampaikan pesan kepada orang lain baik itu melalui lisan, tulisan, maupun isyarat. Keterampilan berbahasa dan menulis ini sangat penting untuk diajarkn sejak dini agar dapat dijadikan bekal pada jenjang yang lebih tinggi dan juga berfungsi melatih siswa dalam menyampaikan atau mengungkapkan buah pikiranya kedalam bentuk tulisan puisi. Dalam pembelajaran bahasa dan sastra Indonesia, siswa dilatih untuk mampu berkomunikasi dengan baik dan benar secara lisan maupun tertulis. Siswa juga dilatih untuk mampu menilai hasil karya sastra bahkan menghasilka sastra. Pembelajaran membaca puisi selama ini merupakan bentuk pembelajaran yang kurang apresiatif. Guru masih mengajarkan membaca puisi dan belum mengajarkan bagaimana syarat-syarat membaca puisi yang baik.

Dengan demikian, pembelajaran membaca puisi dinilai masih kurang sesuai. Dalam pembelajaran bahasa dan sastra Indonesia memiliki tiga tujuan yaitu: Pertama agar siswa memahami dan memanfaatkan karya sastra untuk mengembangkan kepribadian, memperluas wawasan kehidupan, serta meningkatkan pengetahuan, dan kemampuan berbahasa. Kedua, siswa mengekpresikan dirinya dalam medium sastra, dan Ketiga siswa menghargai serta membanggakan sastra Indonesia sebagai khasanah budaya dan intelektual manusia Indonesia. Pembelajaran membaca puisi selama ini, guru kurang memberikan kesempatan kepada siswa untuk memilih puisi, dan melakukan apresiasi membaca puisi. Padahal dengan memilih puisi, siswa akan aktif menentukan puisi yang paling sesuai untuk dibaca. Sehingga siswa bisa mendapatkan bekal membaca puisi dengan interprestasi, vokal, dan penampilan yang sesuai. Dengan demikian guru merupakan faktor yang paling utama dalam proses pembelajaran di kelas.

Guru banyak memegang peranaan yang mau tidak mau harus di laksanakan. Guru yang baik adalah guru yang memiliki kemampuan dasar, seperti kemampuan menguasai metode, teknik serta pendekatan dalam mengajar sehingga guru tidak mungkin lagi menjadi pemberi ilmu atau sumber belajar yang tunggal, namun peserta didik harus diberi motivasi dan kesempatan untuk mencari, menemukan, mempelajari dengan bimbingan gu Guru yang baik adalah guru yang benar-benar memahami tentang tujuan pengajaran, cara merumuskan tujuan mengajar, secara khusus memilih dan menemukan metode mengajar sesuai dengan tujuan yang hendak di capai, memahami bahan pelajaran sebaik mungkin dengan menggunakan berbagai sumber,cara memilih, menentukan, menggunakan alat praga, cara membuat tes, dan menggunakanya( Robert W. Richey dalam Rusman, 2011:26).

Untuk mengajar secara efektif guru harus memberikan kesempatan belajar siswa dengan cara melibatkan siswa secara aktif dan diberi motivasi. Motivasi dapat berfungsi sebagai pendorong usaha dan pencapaian prestasi. Motivasi dapat berfungsi sebagai pendorong usaha dan pencapaian prestasi. Adanya motivasi yang baik dalam belajar akan menunjukan hasil yang baik (Rusman,2011:94). Namun, dalam praktiknya masih ditemukan siswa kurang aktif, karena proses belajar mengajar didominasi oleh guru sebagai yang paling 
tahu yang berperan memberi informasi dan peserta didik dipaksa untuk mendengar, menghafal, dan mengingatnya. Padahal yang paling penting adalah bagaiman siswa mengemukakan pikiranya secara jelas, tepat, dan teratur sehingga mudah dipahami oleh orang lain. Ketrampilan seperti ini perlu ditingkatkan secara terus menerus melalui latihan-latihan, tugas atau dengan cara berdiskusi dan membentuk kelompok kecil agar mereka dapat berbagi dengan orang lain. Untuk itu perlu ada model pengajaran yang melibatkan peserta didik secara langsung dalam pembelajaran, serta teknik yang dapat meningkatkan kemampuan membaca indah teks puisi. Membaca puisi pada hakikatnya merupakan Mengekspresikan pemikiran yang membangkitkan perasaan yang merangsang imajinasi, panca indra dalam susunan berirama (Pradopo dalam Wisang, 2014:13). Oleh karena itu kita harus mempunyai pemahaman yang mendalam tentang bagaimana supaya bisa membaca indah teks puisi.

Melihat kenyataan yang ada bahwa masih banyak siswa kelas SMPK Sinar Pelita Mukusaki Kecamatan Wewaria, tahun ajaran 2020/2021 yang belum mampu membaca indah teks puisi. Minimnya kemampuan siswa dalam membaca indah teks puisi disebabkan oleh kualitas guru. Guru perlu mengenal hasil belajar dan kemajuan belajar siswa yang telah diperoleh sebelumnya. Hal-hal yang perlu diketahui ini antara lain penguasaan pelajaran, ketrampilan-ketrampilan belajar, dan bekerja. Siswa yang cerdas akan lebih berhasil dalam kegiatan belajar, karena ia lebih menangkap dan memahami pelajaran dan mudah berpikir kreatif. Oleh karena itu, peran guru sangat penting dalam mengelolah proses pembelajaran. Terutama dalam pemilihan model pembelajaran harus tepat. Model pembelajaran kooperatif tipe STAD merupakan model pembelajaran yang paling sederhana yaitu menempatkan siswa dalam bentuk kelompok kecil yang heterogen. Model ini menekankan pada siswa untuk saling berinteraksi, memotivasi dan saling membantu dalam menguasai materi pelajaran sehingga apa yang diharapkan dapat tercapai.

\section{METODE PENELITIAN \\ Pendekatan Penelitian}

Jenis pendekatan pada penelitian ini yakni pendekatan deskriptif kuantitatif. Penelitian deskriptif adalah suatu metode penelitian yang di gunakan untuk menggambarkan fenomena-fenomena yang ada, yang berlangsung saat ini atau saat lampau. Secara deskriptif penelitian ini akan memberikan gambaran kemampuan siswa kelas VII SMPK Sinar Pelita Mukusaki dalam membaca puisi dengan menggunakan intonasi yang tepat dan jelas. Secara kuantitatif data yang diperoleh akan diolah dengan menggunakan rumus statistik sederhana, hal ini sesuai dengan pendapat bahwa penelitian kuantitatif adalah penelitian yang mengumpulkan data dan memberikan penafsiran terhadap hasilnya dengan menggunakan angka-angka (Arikunto,2002:10).

\section{Populasi dan Sampel}

Populasi adalah seluruh data yang menjadi perhatian kita dalam suatu ruang lingkup dan waktu yang kita tentukan. Pengertian lain menyebutkan bahwa populasi adalah keseluruhan objek penelitian yang terdiri dari manusia, benda-benda, tumbuh-tumbuhan, gejala-gejala, nilai tes atau peristiwa-peristiwa sebagai sumber data yang memiliki karakteristik tertentu didalam suatu penelitian (Margono, 2010:118). Yang menjadi populasi dalam penelitian ini adalah seluruh siswa/siswi kelas VII SMP Katolik Sinar Pelita Mukusaki yang berjumlah 20 orang. Sampel adalah bagian dari jumlah dan karakteristik yang dimiliki oleh populasi sebagai contoh yang diambil dengan menggunakan cara tertentu (Sugiyono, 2013:81). Berhubung populasi ada 20 orang maka semua siswa tersebut diambil menjadi sampel. Sampel yang digunakan adalah sampel purposive. Siswa yang dipilah sebagai sampel adalah siswa kelas VII SMPK Sinar Pelita Mukusaki yang berjumlah 20 orang. Metode dan Teknik Pengumpulan Data digunakan peneliti dalam pengumpulan data 
di lapangan adalah metode test. Test kemampuan pada siswa disajikan dalam bentuk test uraian meliputi tujuh aspek Penghayatan, penampilan, intonasi, lafal,vokal, mimik, dan jeda.

Tabel 3.1. Aspek Penskoran Penilaian

\begin{tabular}{|l|l|l|}
\hline No & Aspek & Skor \\
\hline 1 & Penghayatan & 10 \\
\hline 2 & Penampilan & 20 \\
\hline 3 & Intonasi & 15 \\
\hline 4 & Lafal & 15 \\
\hline 5 & Vokal & 15 \\
\hline 6 & Mimik & 10 \\
\hline 7 & Jeda & 15 \\
\hline
\end{tabular}

\section{Teknik Pengumpulan Data}

Pengumpulan data dalam penelitian ini dilakukan melalui test performance pada siswa kelas VII SMPK Sinar Pelita Mukusaki,Kecamataan wewaria, Kabupaten Ende Tahun Ajaran 2020/2021. Setelah datadata terkumpul melalui langkah-langkah diatas, kemudian data dianalisis. Untuk menganalisis data peneliti menggunakan metode kuantitatif dengan teknik statistik yang dirumuskan sebagai berikut:

$$
M=\sum \frac{f x}{N}
$$

Keterangan:

$$
\begin{aligned}
& \Sigma(\text { sigma }) \quad=\text { jumlah keseluruhan } \\
& \mathrm{F} \quad=\text { rekuensi } \\
& \mathrm{X} \quad=\text { besarnya nilai } \\
& \mathrm{N} \quad=\text { jumlah }
\end{aligned}
$$

(Nurkencana, 1983:143)

Setelah dianalisis, data disajikan dengan menggunakan langkah-langkah sebagai berikut:

(1) Memeriksa dan menganalisis puisi yang dibaca oleh siswa kelas VII SMPK Sinar Pelita Mukusaki Tahun ajaran 2022/2021

(2) Memberi penskoran terhadap setiap item yang dinilai. (3) Data yang diperoleh dari penskoran akan disajikan dalam sebuah tabel dan data perolehan nilai untuk masing-masing siswa

\section{HASIL DAN PEMBAHASAN}

\section{Penerapan Model Pembelajaran Kooperatif Tipe STAD}

Penerapan model pembelajaran kooperatif tipe STAD dalam membaca indah teks puisi oleh siswa kelas VII SMPK Mukusaki diuraikan sebagai berikut:

1. Kegiatan awal yang mempersiapkan siswa untuk memulai pembelajaran, presensi, dan penyampaian tujuan pembelajaran.

2. Kegiatan inti, siswa dibentuk dalam bentuk kelompok dengan anggota 5 orang, tiap kelompok berciri heterogen terdiri dari laki- laki dan perempuan, berasal dari berbagai suku, memiliki kemampuan tinggi, sedang, dan rendah. Guru membagikan teks puisi yang talah disiapkan berupa tes untuk dibacakan. Anggota tim saling membantu satu sama lain untuk memahami bahan pembelajaran melalui diskusi.

3. Guru bersama siswa menyimpulkan materi pembelajaran.

Pengamatan peneliti tentang penerapan model pembelajaran kooperatif tipe STAD sangat baik, siswa sangat berantusias dalam proses belajar mengajar. Tugas yang diberikan peneliti kepada kelompok dengan menggunakan teks puisi mampu dikerjakan dengan baik. Siswa dalam satu kelompok menunjukan saling membantu untuk menguasai materi pembelajaran yang telah diberikan melalui diskusi antar kelompok. Hampir semua siswa dalam kelompok termotivasi untuk saling bertanya jawab dengan anggota lainya. Siswa dianggab memiliki prestasi yang cukup baik karena sudah dapat memberikan bimbingan kepada teman yang kurang mampu atau teman yang tidak mengikuti proses pembelajaran dengan baik. Sehingga semua anggota kelompok benar-benar memahami apa yang disampaikan oleh peneliti. Untuk mengetahui hasil penerapan model pembelajaran kooperatif tipe STAD, terlebih dahulu peneliti membuat nomor urut dan kode masing- masing siswa sebagai sampel peneliti seperti pada tabel beriku 
Tabel 1.1 Nomor, Nama, dan Kode Siswa/Siswi Kelas VII

\begin{tabular}{|l|l|l|}
\hline No & Nama Siswa & Kode Siswa \\
\hline 1 & Alexander S. P. D. & ASPDS \\
\hline 2 & Alvianus Guru & AG \\
\hline 3 & Bernadinus O. & BOL \\
\hline 4 & Claudia B. Rhonda & CBR \\
\hline 5 & Dionisius S. Karo & DSK \\
\hline 6 & Engelberta F. Oda & EFO \\
\hline 7 & Gabriela Seran & GS \\
\hline 8 & Hildegardis R. & HRD \\
\hline 9 & Joice G. A. Marce & JGAM \\
\hline 10 & Maria Dini Sari Seso & MDSS \\
\hline 11 & Maria M. Suwo & MMS \\
\hline 12 & Maria T. Ndora & MTN \\
\hline 13 & Michael Ryan & MR \\
\hline 14 & Monika A. Pemba & MAP \\
\hline 15 & Nigel H. Renggo & NHR \\
\hline 16 & Primus Rea & PR \\
\hline 17 & Renaldis Asari & RAS \\
\hline 18 & Theresia Bida & TB \\
\hline 19 & Vitalis Pega Rigo & VPR \\
\hline 20 & Yuliana Yeni & YYK \\
\hline & & \\
\hline
\end{tabular}

\subsection{Hasil Penerapan Model Pembelajaran Kooperatf Tipe STAD}

Sebelum peneliti menganalisis hasil test berbentuk lisan kemampuan siswa kelas VII SMPK sinar Pelita Mukusaki Kecamatan Wewaria, Kabupaten Ende tentang penerapan pembelajaran kooperatif tipe STAD untuk memotivasi membaca indah teks puisi. Terlebih dahulu peneliti melakukan kegiatan belajar mengajar tentang cara membaca indah teks puisi sebagai berikut:

\section{a. Kegiatan Awal}

1. Siswa dibagi dalam bentuk kelompok dan tiap kelompok beranggotakan 5 (lima) orang secara heterogen.

2. Peneliti menyampaikan SK yaitu memahami wacana sastra melalui kegiatan membaca puisi dan buku cerita anak, KD yaitu mampu menandai penjedaan dalam puisi yang akan dibacakan,mampu membaca indah puisi,Indikator, dan tujuan pembelajaran.

3. Peneliti dan siswa bertanya jawab tentang pengalaman yang berkaitan dengan puisi

\section{b. Kegiatan inti}

1. Peneliti menyajikan materi tantang cara membaca indah teks puisi. Kegiatan ini bertujuan agar siswa lebih memahami materi yang disajikan peneliti.

2. Peneliti membagikan teks puisi kepada siswa dan siswa di beri waktu beberapa menit untuk membaca puisi tersebut.

3. Peneliti melakukan tes kemampuan siswa dengan cara membaca indah teks puisi yang telah disediakan peneliti.

4. Peneliti mengamati pembacaan puisi siswa, kemudian memberikan nilai kepada masing-masing siswa guna mengetahui kemampuan membaca indah teks puisi siswa.

c. Kegiatan akhir

1. Peneliti memberi komentar dan penjelasan tentang hasil test siswa.

2. Peneliti dan siswa bertanya jawab untuk meluruskan

kesalahpahaman, memberi penguatan, dan penyimpulan.

3. Peneliti menilai hasil tes siswa dengan kriteria sebagai berikut:

a) Baik sekali, jika mendapatkan hasil antara 90-100 yang dikategorikan benar sekali.

b) Baik, jika mendapat hasil antara 80-89 yang di kategorikan mendekati benar.

c) Cukup, jika mendapatkan hasil antara 70-79 yang dikategorikan sebagian besar benar.

d) Kurang, jika mendapatkan hasil $\leq 70$ yang dikategorikan sebagian kecil benar.

Berdasarkan kriteria dalam memberikan penilaian atau skor terhadap hasil tes antara lain, diberi nilai 100 jika benar dan jika salah diberi skor 0 . Untuk mengetahui kemampuan membaca indah teks puisi melalui penerapan pembelajaran kooperatif tipe STAD siswa kelas VII SMPK Sinar pelita Mukusaki tahun ajaran 2020/2021. Peneliti menggunakan instrumen, yaitu: 
Bacalah puisi "Wajah Siapakah" dengan memperhatikan ketujuh aspek yaitu: Penghayatan, penampilan, intonasi, lafal, mimik, dan jeda. Berdasarkan instrumen di atas, maka aspek yang dinilai oleh peneliti yaitu Ketepatan

$$
\begin{aligned}
& 90-100 \quad=\text { Baik sekali } \\
& 80-89=\text { Baik } \\
& 70-79=\text { cukup } \\
& \leq 70=\text { kurang }
\end{aligned}
$$

Hasil tes kerja siswa dalam membaca indah teks puisi melalui penerapan pembelajaran kooperatif tipe STAD, siswa kelas VII SMPK Sinar Pelita Mukusaki Kecamatan Wewaria, Kabupaten Ende tahun ajaran 2020/2021, dapat dilihat pada tabel

\begin{tabular}{|c|c|c|c|c|c|c|c|c|c|c|}
\hline \multirow{3}{*}{ No } & \multirow{3}{*}{ Kelompok } & \multirow{3}{*}{$\begin{array}{l}\text { Nama } \\
\text { Siswa }\end{array}$} & \multicolumn{6}{|c|}{ Aspek yang diukur } & \multirow[b]{3}{*}{100} & \\
\hline & & & $\mathbf{A}$ & B & C D & & & G & & \\
\hline & & & 10 & 20 & 1515 & 15 & 10 & 15 & & \\
\hline \multirow{4}{*}{1} & \multirow{4}{*}{ Kelompok I } & GS & 10 & 10 & 1010 & 10 & 5 & 10 & 65 & 65 \\
\hline & & TB & 10 & 10 & 1010 & 10 & 5 & 10 & 65 & 65 \\
\hline & & HRD & 10 & 10 & 1010 & 10 & 5 & 10 & 65 & 65 \\
\hline & & DSK & 10 & 10 & 1010 & 10 & 5 & 10 & 65 & 65 \\
\hline \multirow{6}{*}{2} & \multirow{6}{*}{$\begin{array}{l}\text { Kelompok } \\
\text { II }\end{array}$} & ASPDS & 10 & 10 & 1010 & 10 & 5 & 10 & 65 & 65 \\
\hline & & BOL & 5 & 15 & 1510 & 15 & 10 & 10 & 80 & 80 \\
\hline & & NHR & 5 & 15 & 1510 & 15 & 10 & 10 & 80 & 80 \\
\hline & & MAP & 5 & 15 & 1510 & 15 & 10 & 10 & 80 & 80 \\
\hline & & $\mathrm{EFO}$ & 5 & 15 & 1510 & 15 & 10 & 10 & 80 & 80 \\
\hline & & CBR & 5 & 15 & 1510 & 15 & 10 & 10 & 80 & 80 \\
\hline \multirow{4}{*}{3} & \multirow{4}{*}{$\begin{array}{l}\text { Kelompok } \\
\text { III }\end{array}$} & $\mathrm{AG}$ & 10 & 15 & 1510 & 15 & 5 & 10 & 75 & 75 \\
\hline & & MDSS & 10 & 15 & 1510 & 15 & 5 & 10 & 75 & 75 \\
\hline & & MMS & 10 & 15 & 1510 & 15 & 5 & 10 & 75 & 75 \\
\hline & & MTN & 10 & 15 & 1510 & 15 & 5 & 10 & 75 & 75 \\
\hline \multirow{6}{*}{4} & \multirow{6}{*}{$\begin{array}{l}\text { Kelompok } \\
\text { IV }\end{array}$} & RAS & 10 & 15 & 1510 & 15 & 5 & 10 & 75 & 75 \\
\hline & & JGAM & 5 & 15 & $15 \quad 15$ & 15 & 5 & 15 & 85 & 95 \\
\hline & & PR & 5 & 15 & $15 \quad 15$ & 15 & 5 & 15 & 85 & 95 \\
\hline & & VPR & 5 & 15 & $15 \quad 15$ & 15 & 5 & 15 & 85 & 95 \\
\hline & & MR & 5 & 15 & 1515 & 15 & 5 & 15 & 85 & 95 \\
\hline & & YYK & 5 & 15 & 1515 & 15 & 5 & 15 & 85 & 95 \\
\hline \multicolumn{3}{|c|}{ Jumlah } & 150 & 275 & 25225 & 27 & 125 & 22 & 1525 & 1525 \\
\hline
\end{tabular}
prestasi berikut:

Tabel 1.2. Daftar Skor Pemerolehan Nilai Tes Prestasi Siswa
A. =Vokal
B. $=$ Mimik
C. = Jeda
D. Penghayatan
E. =Penampilan
F. = Intonasi
G. = Pelafalan

Data yang dihimpun pada tabel diatas menggambarkan bahwa ada beberapa komponen yang dinilai yaitu: penghayatan, (2) penampilan, (3) intonasi, (4) lafal, (5) vokal, (6) mimik, (7) jeda:

Penghayatan, siswa mendapat skor 10 apabila siswa membaca puisi sesuai isi dengan ekspresi, kurang sesuai atau sama sekali tidak sesuai isi puisi dengan ekspresi diberi skor 0

1. Penampilan, siswa mendapat skor 20 apabila siswa mampu membaca puisi dengan sikap dan penampilan yang meyakinkan sesuai dengan isi puisi. Kurang sesuai diberi skor 15, tidak sesuai tetapi berani mengatur ekspresi diberi skor 10, sama sekali tidak sesuai di beri skor 0

2. Intonasi siswa mendapat skor 15 apabila siswa membaca puisi dengan tekanan, atau tinggi rendahnya suara bervariasi sesuai dengan isi puisi, kurang bevariasi diberi skor 10 tidak bervariasi atau monoton dari awal sampai akhir diberi skor 0 .

3. Lafal, siswa mendapat skor 15 apabila ucapanya jelas dan tidak terjadi kesalahan pengucapanya. Ucapanya jelas tetapi terjadi beberapa kesalahan pengucapan diberi skor 10. Ucapanya tidak jelas dan banyak terjadi kesalahan diberi skor 5.

4. Vokal, siswa mendapat skor 15 apa bila pengucapan jelas serta penguasaan intonasi, diksi, dan jeda. Kurang jelas diberi skor 10. Tidak jelas pengucapan tetapi mampu menguasai intonasi, diksi dan jeda diberi skor 5. Apabila tidak jelas sama sekali diberi skor 0 .

5. Mimik, siswa mendapat skor 10 apabila ekspresi gerak tubuh sesuai dengan tuntutan puisi dan tidak gerogi, apabila ekspresi atau gerakan tubuh sesuai dengan isi puisi tetapi gerogi di beri skor 5.

6. Jeda, sisawa mendapat skor 15 apabila pemenggalan frasa atau klausa sangat tepat dalam membaca puisi, pemenggalan frasa atau klausa kurang tepat diberi skor 5. Dari data di atas dapat di lihat bahwa nilai yang diperoleh siswa adalah sebagai berikut: 
Tabel 1.3 : Distribusi Frekuensi

\begin{tabular}{|c|c|c|c|}
\hline No & Nilai (X) & Frekuensi (f) & $\mathbf{F x}$ \\
\hline 1 & 65 & 5 & 325 \\
\hline 2 & 80 & 5 & 400 \\
\hline 3 & 75 & 5 & 375 \\
\hline 4 & 85 & 5 & 425 \\
\hline & umlah & 20 & 1525 \\
\hline \multicolumn{3}{|c|}{ Rata-rata } & 76 \\
\hline
\end{tabular}

menunjukan bahwa hasil kemampuan membaca puisi dengan penerapan pembelajaran kooperatif tipe STAD pada siswa kelas VII SMPK Sinar Pelita Mukusaki tahun ajaran 2020/2021 dikatakan berhasil. Dari hasil temuan diatas terlihat bahwa nilai tertinggi 85 dengan jumlah siswa sebanyak 5 orang dan nilai terendah 65 dengan jumlah siswa 5 orang. Untuk lebih memperjelas pereentase keberhasilan dan kegagalan siswa sampel,dapat dilihat pada table berikut:

Tabel 1.4 : peresentase keberhasilan dan kegagalan siswa

\begin{tabular}{c|l|c|c}
\hline No & \multicolumn{1}{|c|}{ Mampu dan mampu } & jumlah siswa & Presentase \\
\hline 1. & Siswa yang mampu & 15 & $75 \%$ \\
\hline 2. & Siswa yang kurang mampu & 5 & $25 \%$ \\
\hline
\end{tabular}

Dari data di atas siswa yang memperoleh nilai $80-89$ berjumlah 10 orang, dengan kriteria baik. Siswa yang memperoleh nilai 70-79 sebanyak 5 orang, dengan kriteria cukup. Siswa yang memperoleh nilai $\leq 70$ sebanyak 5 orang dengan keriteria kurang. Maka dari hasil di atas penulis menganalisisnya sebagai berikut:

1. Siswa yang berhasil adalah siswa yang mendapat nilai 70 ke atas. Hal ini berarti siswa tersebut mampu membaca indah teks puisi dengan penerapan pembelajaran kooperatif tipe STAD.

2. Siswa yang kurang mampu adalah siswa yang mendapat nilai 70 ke bawah. Hal ini berati siswa tersebut kurang mampu membaca indah teks puisi melaui pembelajran kooperatif tipe STAD.

Siswa yang mengikuti tes berjumlah 20 orang dengan setandar terendah 65 dan standar tertinggi 89. Dengan demikian siswa tersebut mampu membaca indah teks puisi melalui penerapan pembelajaran kooperatif tipe STAD. Berdasarkan analisis di atas,dapat dikatakan bahwa siswa kelas VII SMPK Sinar Pelita Mukusaki Tahun Ajaran 2020/2021mampu membaca indah teks puisi dengan presentase $50 \%$ sebanyak 10 orang dengan nilai tertinggi 85 sedangkan yang kurang mampu sebanyak 5 orang dengan nilai terendah 65. Untuk dapat mengetahui tingkat pemerolehan nilai dapat dilihat melalui table berikut:

Table 1.5. Data peringkat nilai berdasarkan perolehan nilai

\begin{tabular}{|c|c|c|c|c|}
\hline No & $\begin{array}{l}\text { Kode } \\
\text { Siswa }\end{array}$ & $\begin{array}{l}\text { Skor } \\
\text { Ideal }\end{array}$ & $\begin{array}{c}\text { Skor } \\
\text { pemerolehan }\end{array}$ & Keterangan \\
\hline 1 & GS & 100 & 85 & \multirow{10}{*}{$\begin{array}{c}10 \text { orang siswa mencapai } \\
\text { peringkat nilai tergolong } \\
\text { baik dengan rentangan } \\
\text { nilai yaitu } 80-85\end{array}$} \\
\hline 2 & TB & 100 & \multirow[t]{9}{*}{80} & \\
\hline 3 & HRD & 100 & & \\
\hline 4 & DSK & 100 & & \\
\hline 5 & ASPDS & 100 & & \\
\hline 6 & BOL & 100 & & \\
\hline 7 & NHR & 100 & & \\
\hline 8 & MAP & 100 & & \\
\hline 9 & EFO & 100 & & \\
\hline 10 & CBR & & & \\
\hline 11 & AG & 100 & \multirow[t]{5}{*}{75} & \multirow{5}{*}{$\begin{array}{l}5 \text { orang siswa mencapai } \\
\text { peringkat nilai tergolong } \\
\text { cukup dengan rentangan } \\
\text { nilai cukup dengan } \\
\text { retangan nilai } 70-79\end{array}$} \\
\hline 12 & MDSS & 100 & & \\
\hline 13 & MMS & 100 & & \\
\hline 14 & MTN & 100 & & \\
\hline 15 & RAS & 100 & & \\
\hline 16 & JGAM & 100 & \multirow{5}{*}{$\begin{array}{l}6 \\
5\end{array}$} & \multirow{5}{*}{$\begin{array}{l}5 \text { orang siswa mencapai } \\
\text { peringkat nilai tergolong } \\
\text { kurang dengan rentangan } \\
\text { nilai } \leq 70\end{array}$} \\
\hline 17 & PR & 100 & & \\
\hline 18 & VPR & 100 & & \\
\hline 19 & MR & 100 & & \\
\hline 20 & YYK & 100 & & \\
\hline
\end{tabular}

Dari pernyataan di atas, maka dapat dijelaskan bahwa:

1. Dari penelitian yang telah dilakukan pada siswa/siswi kelas VII SMPK Sinar Pelita Mukusaki tahun ajaran 2020/2021 tentang penerapn pembelajaran kooperatif tipe STAD untuk memotivasi membaca indah teks puisi terdapat nilai para siswa/siswi berdasarkan ketuju aspek penting sebagai berikut:

a. Siswa yang berhasil adalah siswa yang mendapat nilai 70 keatas berarti sudah mencapai SKM yang berkisar antara 80-85 dengan nilai tertinggi 85 dan nilai terendah 80 sebanyak 10 orang dengan kriteria baik. Sedangkan nilai yang sudah mencapai KKM berkisar 
antara 70-79. Siswa yang tergolong cukup sebanyak 5 orang dengan nilai tertinggi 79 dan nilai terendah 70 dengan rentangan nilai 70-79.

b. Siswa yang kurang mampu adalah siswa yang mendapat nilai 70 kebawah. Hal ini berarti siswa tersebut kurang mampu membaca indah teks puisi melalui penerapan pembelajaran kooperatif tipe STAD, dengan nilai 65 sebanyak 5 orang denga rentangan nilai $\leq 70$ dan siswa/siswi yang dibawa KKM berkisar antara 60-69.

2. Gambaran hasil tes yang diperoleh siswa, bila disesuaikan dengan standar ketuntasan minimal (SKM) mata pelajaran bahasa Indonesia pada SMPK Sinar Pelita Mukusaki yaitu 70, maka penliti dapat menjelaskan bahwa siswa yang berhasil mendapat nilai 70 keatas sebanyak 15 orang dari 20 orang siswa yang diteliti dengan peresentasenya $75 \%$. Hal ini menunjukan siswa/siswi tersebut mampu membaca indah teks puisi melalui penerapan model pembelajaran kooperatif tipe STAD yang diterapkan oleh peneliti.

3. Siswa yang kurang mampu adalah siswa yang mendapat nilai kurang dari 70 . Hal ini berarti siswa ersebut memiliki kemampuan yang kurang dalam membaca indah teks puisi melalui penerapan pembelajaran kooperatif tipe STAD yang diterapkan peneliti. Siswa yang mendapat nilai kurang dari 70 sebanyak 5 orang dengan peresentase $25 \%$.

4. Keberhasilan yang diperoleh tentunya tidak terlepas dari respon siswa/siswi yang tinggi mengikuti kegiatan pebelajaran di kelas dan juga berbagai cara yang ditempu peneliti agar siswa/siswi bisa menerima dan memahami materi sesuai model pembelajaran yang diterapkan.

1. Siswa yang mengikuti tes uraian berbentuk lisan dalam pembelajaran membaca indah teks puisi melalui penerapan pembelajaran kooperatif tipe STAD sebanyak 20 orang dengan nilai pemerolehan nilai tetinggi mencapai 85 dengan perincian nlai sebagai berikut:

a. Sebanyak 10 orang siswa/siswi yang nilainya mencapai $80-85$ sebagai nilai tertinggi dan tergolong baik.

b. Sebanyak 5 orang siswa/siswi yang nilainya mencapai $70-79$ sebagai nilai tertinggi 75 dan tergolong cukup.

c. Sebanyak 5 orang siswa/siswi yang nilai mencapai $\leq 70$ sebagai nilai terendah 65 dan terolong kurang.

2. siswa/siswi kelas VII yag tergolong mampu di atas sebayak 15 orang dengan jumlah nilai rata-rata yang diperoleh mencapai 75,25\%.

\section{Kesimpulan}

Berdasarkan temuan dan pembahasan, maka hasil penelitian ini dapat disimpulkan sebagai berikut: Kemampuan membaca indah puisi dengan menggunakan penerapan pembelajaran kooperatif tipe STAD pada siswa kelas VII SMPK Sinar Pelita Mukusaki Kabupaten Ende Tahun Ajaran 2020/2021 dapat berjalan dengan baik. Hal ini dapat dibuktikan semua siswa kelas VII SMPK Sinar Pelita Mukusaki yang berjumlah 20 orang berahsil membaca indah teks puisi dalam penerapan pembelajaran kooperatif tipe STAD. Dengan nilai 95-100 sebanyak 5 orang dengan kriteria baik sekali dan Siswa yang memperoleh nilai 80-89 sebanyak 15 orang, dengan kriteria baik.

\section{Saran}

1. Bagi guru

a. Agar menerapkan pembelajaran kooperatif tipe STAD dalam pembelajaran di kelas. Tingkatkan peran guru sebagai fasilitator dalam pembelajaran di kelas

b. Budayakan pembelajaran yang aktif, kreatif, efektif dan menyenangkan

2. Bagi siswa
a. Memiliki rasa ingin tahu, percaya diri, mandiri dan bekerja sama.
b. Tingkatkan keaktifan dalam proses 
belajar mengajar.

3. Bagi sekolah

Harus dapat menyiapkan berbagai sarana dan prasarana yang lengkap agar dapat menunjang prestasi belajar siswa, khususnya pembelajaran bahasa Indonesia.

4. Bagi orang tua

Orang tua harus memperhatikan segala kebutuhan dan perlengkapan anaknya, buku-buku yang dapat menunjang kemampuan dalam pembelajaran bahasa Indonesia

\section{DAFTAR PUSTAKA}

Abdul Majid, 2013. Strategi pembelajaran. Bandung: PT. Remaja Rosdakarya A.M, Sardiman. 2004. Interaksi dan Motivasi Belajar Mengajar. Jakarta: Raja Grafi. Persada

Aminuddin, 2011. Pengantar Apresiasi Karya Sastra. Bandung: Penerbit Sinar Baru.Guntur Tarigan, Henry. 2008. Membaca Sebagai Suatu Ketrampilan Berbahasa. Bandung: Penerbit Angkasa.

Jakarta: Kencana, 2008.

Purwanto. 2009. Evaluasi Hasil Belajar. Yogyakarta:Pustaka Pelajar. Roestyah. 1991. Strategi Belajar Mengajar. Jakarta: Rineka Cipta.

Rusman. 2011. Model-Model Pembelajaran Mengembangkan Profesionalisme Guru. Jakarta: PT Rajagrafindo Persada.

Rusman. 2012. Model-Model Pembelajaran Mengembangkan Profesionalisme Guru. Jakarta: Rajawali Pers.

Sanjaya, Wina, Strategi Pembelajaran: Berorientasi Standar Proses Pendidikkan,

Semi, M. Atar. 2007. Dasar-Dasar Ketrampilan Menulis. Bandung: Angkasa. Ugha,

Slavin, Robert E, Cooperatif Learning: Teori Riset dan Paraktik, Bandung: Nusa Media, 2009.

Wilda. 2013. "Wajah Siapakah" dalam kumpulan puisi Mengalirlah Sunyi. Ende : Nusa Indah.
Wissang Oliva, Imelda. 2014. Memahami Puisi dari Apresiasi Menuju Kajian. Yogyakarta: Penerbit Ombak. 